\title{
Genetic Variability in Puccinia psidii Populations as Revealed by PCR-DGGE and T-RFLP Markers
}

Maria Carolina Quecine and Andressa Peres Bini, Laboratory "Max Feffer" of Genetic of Plants, Department of Genetics; Emiliana
R. Romagnoli and Fernando Dini Andreote, Department of Soil Science; and David Henry Moon and Carlos Alberto Labate,
Laboratory "Max Feffer" of Genetic of Plants, Department of Genetics, Escola Superior de Agricultura "Luiz de Queiroz", University Laboratory "Max Feffer" of Genetic of Plants,
of São Paulo, 13418-900, Piracicaba-SP, Brazil

\begin{abstract}
Quecine, M. C., Bini, A. P., Romagnoli, E. R., Andreote, F. D., Moon, D. H., and Labate, C. A. 2014. Genetic variability in Puccinia psidii populations as revealed by PCR-DGGE and T-RFLP markers. Plant Dis. 98:16-23.

Eucalyptus rust caused by Puccinia psidii is responsible for losses of approximately $20 \%$ of young Eucalyptus plants, depending on the environmental conditions and the geographic location. Despite its economic importance, there are few studies describing the genetic variability in $P$. psidii populations that infect different host plants. In the present study, we evaluated the ribosomal DNA internal transcribed spacer region (rDNA-ITS) using polymerase chain reaction denaturing gradient gel electrophoresis and terminal restriction fragment length polymorphism to assess the genetic variability in $P$. psidii populations infecting different Eucalyptus spp. and hybrids, as well as guava, jabuticaba, and syzygium. These culture-independent methods were

which they were collected. In general, the results from both techniques showed that the populations collected from guava, jabuticaba, and syzygium were different from and had a greater level of diversity than the Eucalyptus rust populations. The sequencing of cloned rDNA-ITS fragments confirmed that the vast majority of the profiles generated were from $P$. psidii. This analysis also revealed interesting single-nucleotide polymorphisms. Therefore, these culture-independent methods are suitable for the rapid assessment of genetic variability within and between populations of this biotrophic fungus on a variety of host species and could be a tool to study the evolution of this pathogen and its interactions with host plants.
\end{abstract} efficient in differentiating populations based on the host species from
Eucalyptus spp. are among the most important cultured plant species. More than 19 million ha are planted worldwide, of which 6.4 million are planted in the Americas. Eucalyptus spp. are used as a raw material for several industrial purposes. Brazil has the second largest commercial plantations of Eucalyptus, with $20 \%$ of the worldwide total (26), and is globally recognized as the fourth major producer of cellulose pulp. In 2010, the Brazilian pulp and paper industry produced 14.1 million tons of cellulose (almost exclusively from Eucalyptus spp.) and 9.8 million tons of paper (1). Significant losses occur in Eucalyptus production due to phytopathogens such as Puccinia psidii, the causal agent of Eucalyptus rust.

P. psidii affects many species of Eucalyptus around the world with differing degrees of severity; Eucalyptus grandis is one of the most susceptible host species $(3,18)$. The presence of $P$. psidii in commercially planted areas is a significant problem for wood production. P. psidii can also affect other hosts from the Myrtaceas family, such as guava, jabuticaba, and syzygium (16).

In 1973, the first severe outbreak of $P$. psidii in E. grandis nurseries and young plantations (less than 18 months old) occurred in Brazil $(22,23)$. Since then, $P$. psidii outbreaks have been reported in many countries in the Americas, the Caribbean, the Pacific Islands, and Asia. Outbreaks have also been reported in South Africa and Taiwan (27) but the identity of the pathogen was not confirmed for these outbreaks and no further outbreaks have been reported.

The selection of resistant progeny from Eucalyptus clones has been a challenge for the forestry industry. Selection is normally

Corresponding author: C. A. Labate, E-mail: calabate@usp.br

* The $\boldsymbol{e}$-Xtra logo stands for "electronic extra" and indicates that supplementary information is available online.

Accepted for publication 5 August 2013.

http://dx.doi.org/10.1094/PDIS-03-13-0332-RE

(C) 2014 The American Phytopathological Society performed using either natural infection in the field or artificial inoculation under controlled conditions (17). This selection is important for breeding programs; however, little is known about the genetic variability in the pathogen populations (31). The frequent appearance of new variants of this phytopathogen effectively breaks the resistance achieved in commercial Eucalyptus clones (E. Gonzales, personal communication).

There is no documented study that has achieved spore multiplication on synthetic media for this biotrophic fungus. Therefore, it is laborious to produce spores using susceptible plants to grow and purify the isolates. During this procedure, some individuals may be indirectly selected and the actual level of fungal diversity may be underestimated. One alternative that has not been previously reported for $P$. psidii is the use of molecular techniques based on culture-independent methods to characterize the genetic variability in populations of this pathogen. This research aimed at assessing the genetic variability in $P$. psidii populations using two cultureindependent methods: polymerase chain reaction denaturing gradient gel electrophoresis (PCR-DGGE) and terminal restriction fragment length polymorphism (T-RFLP). The information generated concerning genetic diversity will provide a better understanding of how this pathogen changes when it colonizes different hosts. Resistance evaluation tests can also be modified to use more than one isolate for breeding programs and for the improvement of management techniques for Eucalyptus rust in Brazil and other countries.

\section{Materials and Methods}

P. psidii population samples. All $P$. psidii populations from $E u$ calyptus spp. were collected in May 2011 in Itapetininga, SP, Brazil, in Futuragene's small experimental area used to select rustresistant and -susceptible Eucalyptus clones. In the experimental area, many Eucalyptus spp. and clones were randomly planted with a spacing of approximately 2 by $2 \mathrm{~m}$. The urediniospores were sampled from leaf lesions. The pustule amount in the leaf was dependent on the degree of host susceptibility. All pustules were sampled from each leaf. Each biological repetition was composed of three leaves from a single plant. We sampled three plants per 
clone, which were used in all assays with three biological replications. The selected Eucalyptus clones were as follows: E. grandis (clone 1600 [PEG1600]), E. grandis (clone D901 [PEGM9]), E. urophylla $(\mathrm{PEU})$, E. grandis $\times$ urophylla $(\mathrm{PEGU})$, E. grandis $\times$ brassiana (clone MA2000 [PEGB]), and E. grandis $\times$ dunni (clone 1366 [PEGD]). The following three Myrtaceae hosts were also sampled: guava (Psidium guajava [PGuava]), jabuticaba (Myrciaria cauliflora [PJab]), and syzygium (Syzygium jambos [PSyz]). The selection of hosts was based on differential levels of susceptibility (Fig. 1). The urediniospores were immediately frozen in liquid nitrogen and stored at $-80^{\circ} \mathrm{C}$ for future DNA extraction.

DNA extraction. Total genomic DNA was extracted from 20 to $50 \mathrm{mg}$ of urediniospores using the DNAeasy Plant Mini Kit (Qiagen) according to the manufacturer's instructions. The urediniospores were first ground with a pestle and mortar using liquid nitrogen. The concentration and quality of DNA were estimated using a NanoDrop 3300 spectrophotometer (Thermo Scientific) and gel electrophoresis.

Genetic variation in Puccinia psidii populations. An analysis of the genetic variation in Puccinia psidii populations was performed using the PCR-DGGE and T-RFLP culture-independent methods. The ribosomal DNA internal transcribed spacer region (rDNA-ITS) target region was used as the gene marker.

Fungal DNA amplicons from the rDNA-ITS region were obtained as described by Anderson et al. (6), using the primers EF4 (GGA AGG GRT GTA TTT ATT AG) and ITS4 (TCC TCC GCT TAT TGA TAT GC) in the first reaction. This was followed by a second amplification using the nested primers ITS1 F (5'-GC clamp-CTT GGT CAT TTA GAG GAA GTA A) and ITS2 (GCT GCG TTC TTC ATC GAT GC). PCRs were carried out using a GeneAmp PCR System 9700 thermal cycler (Applied Biosystems) in 50-ml reaction volumes containing approximately $50 \mathrm{ng}$ of template DNA; 10 pmol each primer; $2 \mathrm{mM} \mathrm{MgCl}_{2} ; 250 \mathrm{mM}$ each dATP, dCTP, dGTP, and dTTP; $1 \times$ PCR buffer; $0.05 \mathrm{ml}$ of a bovine serum albumin (BSA) solution $(10 \mathrm{mg} / \mathrm{ml})$; and $2.5 \mathrm{U}$ of highfidelity DNA polymerase. Cycling parameters were $94^{\circ} \mathrm{C}$ for 5 min; followed by 35 cycles of $94^{\circ} \mathrm{C}$ for $30 \mathrm{~s}, 55^{\circ} \mathrm{C}$ for $30 \mathrm{~s}$, and $72^{\circ} \mathrm{C}$ for $1 \mathrm{~min}$; with a final extension of $72^{\circ} \mathrm{C}$ for $5 \mathrm{~min}$. For the second round of amplification, the PCR product was diluted 1:10 ( $\mathrm{vol} / \mathrm{vol}$ ). The PCR and cycling conditions were as described above, except that formamide substituted for BSA (1\%, vol/vol) in the reactions. Prior to DGGE analysis, the resulting amplicons were characterized by electrophoresis in agarose gels to determine their sizes and the specificity of the reactions. DGGE analyses were performed using a DCode Universal Mutation Detection System (Bio-Rad). The PCR amplicons (300 ng) were loaded onto
$6 \%$ polyacrylamide gels in $0.5 \times$ Tris-acetate-EDTA buffer $(20 \mathrm{mM}$ Tris-acetate and $1 \mathrm{mM}$ EDTA, $\mathrm{pH}$ 8.0). The polyacrylamide gels contained denaturing gradients of 20 to $65 \%$ (the $100 \%$ denaturant fraction contained $7 \mathrm{M}$ urea and $40 \%$ formamide). The gels were run at $200 \mathrm{~V}$ for $4 \mathrm{~h}$ at $60^{\circ} \mathrm{C}$. The gels were then soaked for $30 \mathrm{~min}$ in SYBR Gold nucleic acid staining solution (Invitrogen) and digitally imaged under UV light using a StormTm 845 densitometer (GE Healthcare). The DGGE profiles were normalized and compared using GelComparII software (Applied Maths). The DGGE gel contained one replicate of each sample. Three independent DGGE gels, one per biological repetition, were run in total. The resulting bands were identified and added to a matrix that comprised the relative area of each band in each sample and was generated for further analyses.

For T-RFLP analysis, DNA samples were amplified using the following two primers specific for the rDNA-ITS: FAM-ITS1F $\left(5^{\prime}\right.$ TCCGTAGGTGAACCTGCGG-3') and ITS4 (5'-TCCTCCGCT TATTGATATGC-3'). The amplification reaction was conducted

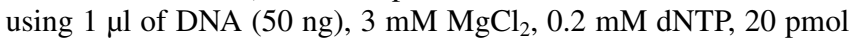
each primer, $1 \times$ PCR buffer, and $2.5 \mathrm{U}$ of Taq DNA polymerase in a total reaction volume of $50 \mu \mathrm{l}$. The amplification conditions were as follows: $94^{\circ} \mathrm{C}$ for $1.5 \mathrm{~min} ; 13$ cycles of $35 \mathrm{~s}$ at $94^{\circ} \mathrm{C}, 55 \mathrm{~s}$ at $55^{\circ} \mathrm{C}$, and $45 \mathrm{~s}$ at $72^{\circ} \mathrm{C} ; 13$ cycles of $35 \mathrm{~s}$ at $94^{\circ} \mathrm{C}, 2 \mathrm{~min}$ at $55^{\circ} \mathrm{C}$, and $45 \mathrm{~s}$ at $72^{\circ} \mathrm{C} ; 9$ cycles of $35 \mathrm{~s}$ at $94^{\circ} \mathrm{C}, 3 \mathrm{~min}$ at $55^{\circ} \mathrm{C}$, and $45 \mathrm{~s}$ at $72^{\circ} \mathrm{C}$; and $10 \mathrm{~min}$ at $72^{\circ} \mathrm{C}(25)$. We performed three replications per reaction to mitigate the effects of PCR amplification bias introduced during DNA extraction (21). For each sample, the replicate PCR reactions were cleaned up using the GFX PCR Clean-Up kit according to the manufacturer's instructions. The samples were then combined.

The digestion reactions were performed using $200 \mathrm{ng}$ of amplification product and $5 \mathrm{U}$ of HaeIII enzyme according to the manufacturer's instructions $(8,13)$. Each sample was analyzed twice in a Genetic Analyzer 3500 automatic sequencer (Applied Biosystems) according to the manufacturer's recommendations; the blue matrix and a 600-bp marker were used. The electropherograms were examined using GeneMapper 4.1 software and grouped according to the following allele parameters: size, height, and peak area. The TRFLP data generated a matrix and the peak areas were used for further data analysis.

Data analysis. The matrices generated from both PCR-DGGE and T-RFLP were used for the molecular analysis of $P$. psidii populations as described below. The non-metric multidimensional scaling analysis was performed using Primer 6 software (Primer) and the Bray-Curtis model for similarity was adopted. The specific distribution of populations according to the host was obtained, as
A

\begin{tabular}{llll}
\hline Host & Location & Plant tissue & Susceptibility \\
\hline Eucalyptus grandis & Itapetininga & Leaves & Susceptible \\
E. grandis $x$ dunni & Itapetininga & Leaves & Intermediate \\
E grandis $x$ brassiana & Itapetininga & Leaves & Intermediate \\
E. grandis $x$ uruphylla & Itapetininga & Leaves & Intermediate \\
E. urophylla & Itapetininga & Leaves & Resistant \\
Psidium guava & Piracicaba & Fruit & Susceptible \\
Myrciaria cauliflora & São Paulo & Fruit & Susceptible \\
Syzygium jambos & Itatinga & Leaves & Susceptible \\
\hline
\end{tabular}

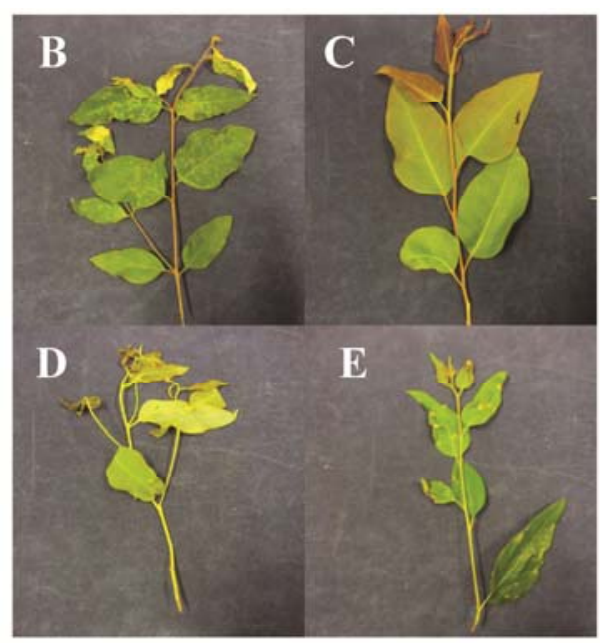

Fig. 1. Sampled plants used to access the genetic variability of Puccinia psidii populations. A, Material was sampled from different locations and tissues of Myrtaceae species with different degrees of susceptibility to P. psidii: B, Eucalyptus grandis; C, E. urophylla; D, E. grandis $\times$ dunni; and E, E. grandis $\times$ urophylla. Susceptibilities of the host species were classified according to Alfenas et al. (2) and Zauza et al. (60). 
well the following diversity parameters indexes: total profile, profile value (band intensities), species richness (Margalef), Shannon, and Simpson diversity.

We also performed an analysis of similarities (ANOSIM) using the PAST software program (29) to prove that there were significant differences between the samples (14). The $R$ value was calculated. Large, positive $R$ (up to 1 ) values signified dissimilarity between groups and $R=0$ indicated nonsignificant dissimilarities between the groups. Intermediate $R$ values $(1<R>0)$ are commonly interpreted as partial dissimilarities between the groups (15).

Correlations between the genetic variability in $P$. psidii populations and the plant hosts were determined by multivariate analysis using the software Canoco 4.5 for Windows (Biometris) and following previously described procedures $(7,46,53)$. A detrended correspondence analysis (DCA) was performed first to calculate the gradient distribution of "species" in all plant hosts. Because we observed a linear distribution of "species" in the fungal community (gradient in the first axis < 4.0), our data were analyzed using a principal component analysis (PCA). The axis values showed the percentage of variance in each population.

Construction and analysis of clone libraries. PCR amplicons from nine samples from each population were pooled to validate the PCR-DGGE and T-RFLP results. For the clone libraries, amplicons were generated using the same primer set described above, except that the primer ITS1 F was used without the GC clamp. Amplicons from the same population were mixed, and the resulting amplicon pools were purified and cloned into the pGEM-T Easy cloning vector (Promega). The resulting plasmids were transformed into Escherichia coli Top10 (Invitrogen).

Plasmid DNA containing inserts was extracted by alkaline lysis. DNA sequencing was performed using this plasmid DNA and the Big DyeTerminator Cycle Sequencing kit (Sigma-Aldrich) according to the manufacturer's instructions. The amplified fragments were purified according to Sambrook and Russell (48) and sent for sequencing at the Center of Functional Analysis, Escola Superior de Agricultura "Luiz de Queiroz", University of São Paulo, Piracicaba-SP, Brazil, which uses a Genetic Analyzer 3130XL system platform (Applied Biosystems). For all clones, the rDNA-ITS region was sequenced with ITS-1F and ITS-4R primers.

Sequence assembly and alignment. Consensus sequences were manually aligned using MEGA v5.1 (52) and BioEdit 7.0 software (28) by inserting gaps. rDNA-ITS sequences were aligned on the basis of similarity using the sequence alignment software CLUSTAL-W 1.7 (54). The identification of sequences was performed
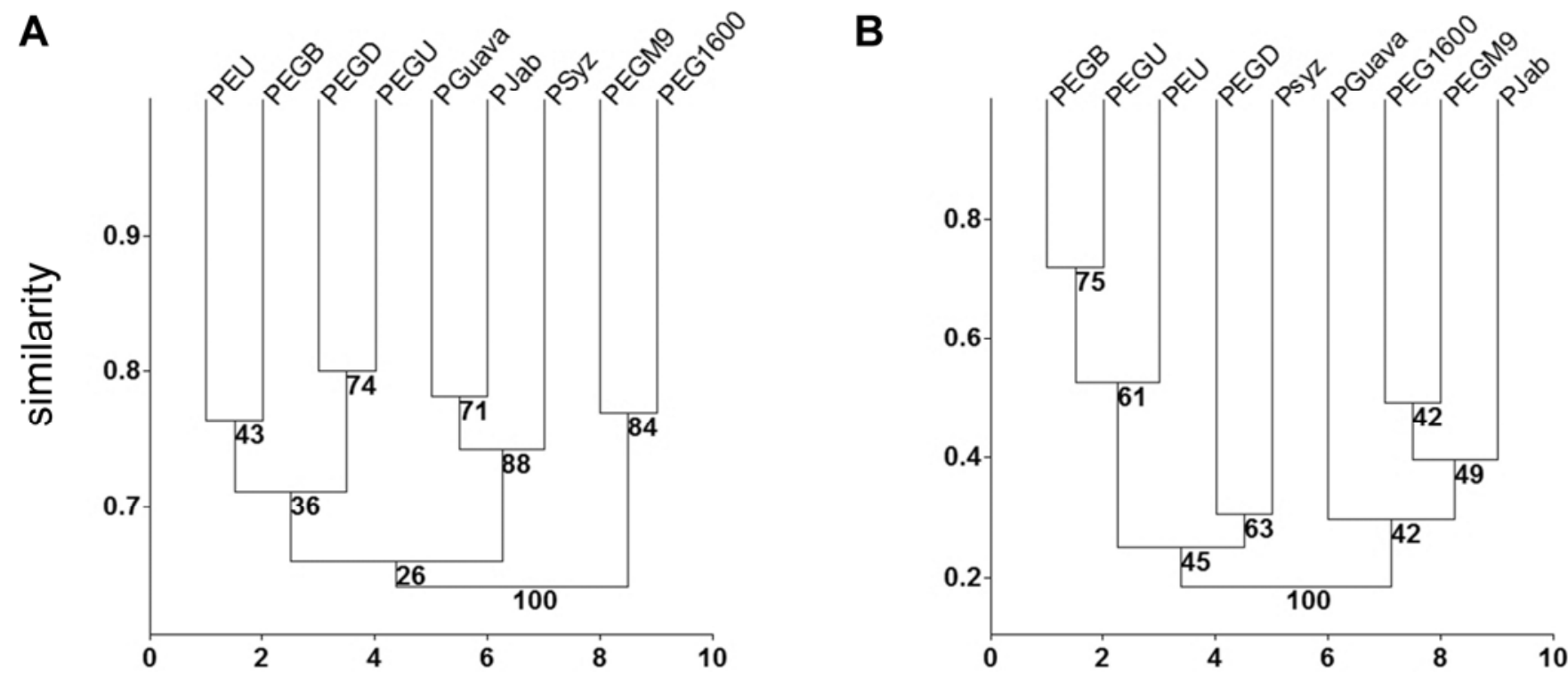

Fig. 2. Clustering of similarity of Puccinia psidii populations from Eucalyptus grandis, clone M9 (PEGM9); E. grandis, clone 1600 (PEG1600); E. urophylla (PEU); E. grandis × brassiana $(\mathrm{PEGB})$; E. grandis $\times$ dunii $(\mathrm{PEGD);} \mathrm{E.} \mathrm{grandis} \times$ urophylla (PEGU); guava (PGuava); jabuticaba (PJab); and syzygium (PSyz) using A, polymerase chain reaction denaturing gradient gel electrophoresis and $\mathbf{B}$, terminal restriction fragment length polymorphism. Bootstrap values represent the means of 1,000 repetitions.

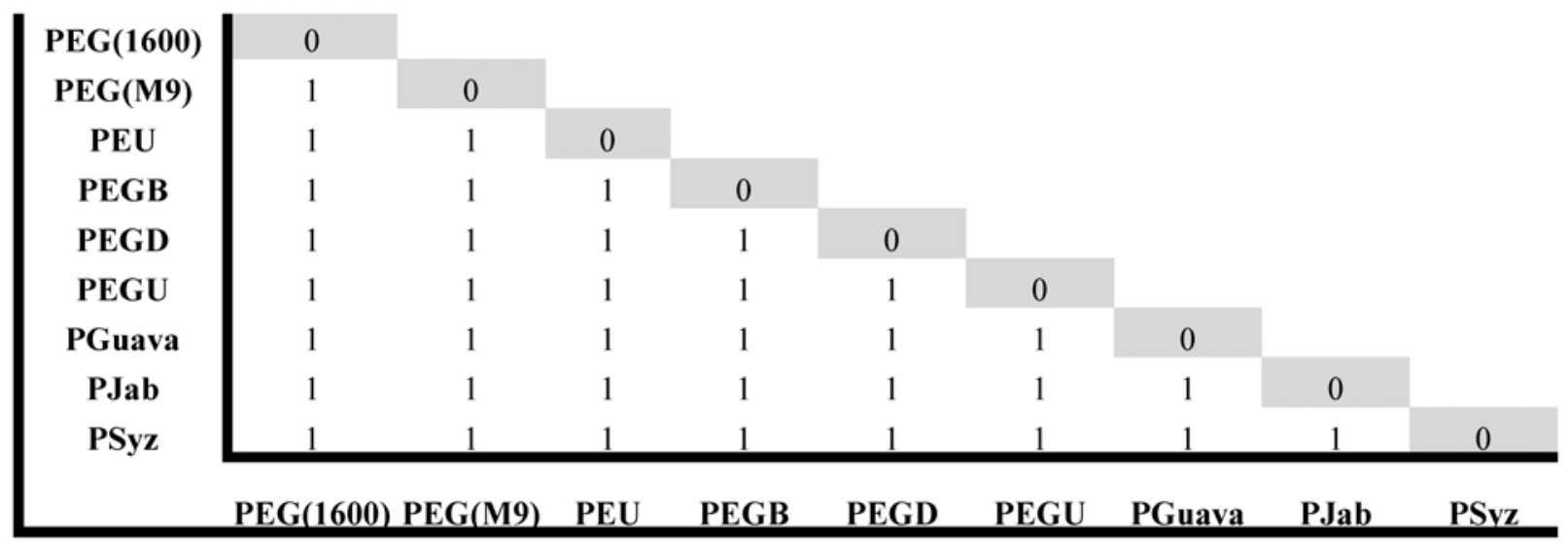

Fig. 3. Analysis of similarities (ANOSIM; one way) in Puccinia psidii populations from Eucalyptus grandis, clone M9 (PEGM9); E. grandis, clone 1600 (PEG1600); E. urophylla $(\mathrm{PEU})$; E. grandis $\times$ brassiana (PEGB); E. grandis $\times$ dunii $(\mathrm{PEGD);} \mathrm{E.} \mathrm{grandis} \times$ urophylla (PEGU); guava (PGuava); jabuticaba (PJab); and syzygium (PSyz). Large positive $R$ values (up to 1) signify a high level of dissimilarity between groups. The ANOSIM generated by polymerase chain reaction denaturing gradient gel electrophoresis and terminal restriction fragment length polymorphism were identical, as shown above. 
using BLASTn and the nucleotide collection (nr/nt) database (http://www.ncbi.nlm.nih.gov/blast/).

Neighbor-joining analysis was conducted using Megav5.1 software, with the branch support values obtained after 1,000 heuristic search pseudoreplicates. Sequences presented in this study were submitted to GenBank (accession numbers KC543195 to KC543330).

\section{Results}

Similarity analysis of the populations. All three of the replicate PCR-DGGE gels from the rDNA-ITS region showed a highly similar complex profile between replicates, suggesting that variation was very low within a host species. After clustering analysis, we observed a clear grouping of the Eucalyptus grandis populations (PEG1600 and PEGM9) as well the clustering of the populations from guava, jabuticaba, and syzygium (Fig. 2A). The T-RFLP profiles of the $P$. psidii populations were also used to perform the same type of analysis, which produced similar clustering to that generated by the PCR-DGGE data from E. grandis (PEG1600 and PEGM9), PGuava, and PJab populations. Using the T-RFLP data, PSyz clustered together with populations from other Eucalyptus hosts (Fig. 2B)

By ANOSIM analysis, we found that the $R$ value $=1$ for both the RCR-DGGE and T-RFLP data sources. This demonstrates that all populations analyzed are dissimilar (Fig. 3). The results provide a consistent separation of the populations according to the host plant and demonstrate the important role of host selection in shaping $P$. psidii populations.

Diversity analysis. Using PCR-DGGE data, a greater degree of richness and higher levels of diversity were observed in the $P$. psidii populations from guava, syzygium, and jabuticaba compared with populations from Eucalyptus hosts. Due to the higher sensitivity of T-RFLP in detecting polymorphisms, we obtained a greater number of markers ("peaks") resulting in a higher variation of the Shannon index in the fungal populations when compared with the data obtained though PCR-DGGE.

Based on the T-RFLP data, we observed higher diversities in the P. psidii populations from syzygium, jabuticaba, and guava than in those from the Eucalyptus hosts; one exception was the PEG1600 population, in which the second highest Shannon index was observed (Table 1). Using the PAST software to compare the diversity index ( $t$ test), we obtained significant values of separation $(P<$ $0.05)$ for all the samples we compared. This result demonstrates that the diversity index differs significantly from host to host (data not shown).

PCA analysis. DCA analysis of the distribution of species revealed gradient lengths of 1.294 and 3.403 in size when using the PCR-DGGE and T-RFLP data, respectively. This linear distribution of data justified the use of PCA analysis. From the PCR-DGGE data, we observed a clear clustering among the PSyz, PGuava, and PJab populations in one quadrant as well as the clustering of PEGM9 and PEG1600 in another quadrant (Fig. 4A).

The proposed groups corroborate the clustering analysis. Groups with more diversity (the group containing PSyz, PGuava, and PJab and the group containing PEGM9 and PEG1600) were located in the same quadrant (Fig. 4B).

rDNA-ITS region sequences. In all, 96 rDNA-ITS clones were selected for storage from each of the $P$. psidii populations; approximately $20 \%$ of these clones were sequenced in both directions (forward and reverse). The resulting consensus sequences were analyzed by BLASTn. All sequences were highly similar to the rDNA-ITS from $P$. psidii, with the exception of six clones (three from PEGU, one from PEG1600, one from PGuava, and one from PEGD) that showed homology with rDNA-ITS from uncultured soil fungi or other species. Overall, the sequences had 98.4 to $99.8 \%$ similarity to the $P$. psidii reference sequence in GenBank (EU07148.1) and almost complete coverage of the ITS1, 5.8S rRNA gene, and ITS2.

The $P$ distance of the aligned sequences was calculated by MEGA, giving a value of 0.003 and a $1-P$ value of 0.997 . A value
$1-P>0.65$ is sufficient for phylogenetic analysis. The dendrogram clearly separated some clones from the PGuava, PSyz, and PJab populations into separate clusters (Fig. 5A). We also observed a cluster containing only clones from the Eucalyptus hosts. Other clones were distributed around the dendrogram, suggesting that pathogen flux exists between hosts (Fig. 5A). Alignment was observed for the 135 sequences in the presence of 41 loci with singlenucleotide polymorphism (SNPs). Some SNPs occurred in nearly all the evaluated populations (Fig. 5B), whereas others were population specific for the PJab and PSyz populations (Fig. 5C; Supplementary Information).

\section{Discussion}

Many groups have studied rust fungi at the molecular level to highlight genetic variability, such as in $P$. triticina, $P$. graminis, and $P$. striiforms $(2,4,10,44,49,56)$. However, there are only a few studies on the genetic variability of the Eucalyptus rust fungi $P$. psidii and most studies reported only on the physiological diversity of this pathogen and its relation to host specificity. Currently, two studies have reported on the genetic variability of $P$. psidii isolates using microsatellites as markers $(61,62)$, indicating how little we know about the variability of this pathogen. One reason for this lack of information could be the biotrophic lifestyle of this pathogen, which makes it difficult to cultivate in vitro. We present here an alternative for overcoming this problem using two culture-independent methods-PCR-DGGE and T-RFLP-to evaluate the diversity of $P$. psidii populations.

Both techniques are powerful for the culture-independent molecular analysis of fungal populations; therefore, they are preferable for many ecological applications, particularly when combined with techniques such as cloning (19). DGGE is a DNA fingerprinting technique that has been widely used in molecular studies to describe and compare microbial populations $(41,47)$. PCR-DGGE is able to discriminate between PCR products of similar size with different base composition, allowing for the analysis of diversity within fungal communities $(33,55,59)$. The large number of polymorphic bands in DGGE illustrates the high sensibility of this method. In theory, this method can detect differences between

Table 1. Diversity parameters of fungal populations using polymerase chain reaction denaturing gradient gel electrophoresis (PCR-DGGE) and terminal restriction fragment length polymorphism (T-RFLP)

\begin{tabular}{|c|c|c|c|c|c|}
\hline \multirow[b]{2}{*}{ Populations $^{\text {b }}$} & \multicolumn{5}{|c|}{ Diversity parameters ${ }^{a}$} \\
\hline & $S$ & $N$ & $d$ & $H^{\prime \prime}(\operatorname{loge})$ & $1-\lambda$ \\
\hline \multicolumn{6}{|l|}{ PCR-DGGE } \\
\hline PEG1600 & 70 & 29 & 20.49 & 4.115 & 1.017 \\
\hline PEGM9 & 72 & 30 & 20.89 & 4.151 & 1.017 \\
\hline PEU & 76 & 30 & 22.12 & 4.174 & 1.017 \\
\hline PEGB & 81 & 33 & 22.97 & 4.264 & 1.016 \\
\hline PEGD & 73 & 30 & 21.17 & 4.165 & 1.017 \\
\hline PEGU & 77 & 30 & 22.26 & 4.216 & 1.017 \\
\hline PGuava & 86 & 34 & 24.13 & 4.333 & 1.016 \\
\hline PJab & 88 & 35 & 24.5 & 4.356 & 1.015 \\
\hline PSyz & 95 & 35 & 26.41 & 4.402 & 1.015 \\
\hline \multicolumn{6}{|l|}{ T-RFLP } \\
\hline PEG1600 & 231 & 747,573 & 17.0 & 3.61 & 0.92 \\
\hline PEGM9 & 138 & 602,875 & 10.3 & 2.00 & 0.57 \\
\hline PEU & 128 & 925,583 & 9.2 & 2.53 & 0.77 \\
\hline PEGB & 118 & $1,002,122$ & 8.5 & 1.84 & 0.66 \\
\hline PEGD & 129 & 933,911 & 9.3 & 2.57 & 0.75 \\
\hline PEGU & 119 & 959,922 & 8.6 & 2.41 & 0.74 \\
\hline PGuava & 154 & 315,958 & 12.1 & 3.76 & 0.93 \\
\hline PJab & 245 & 818,403 & 17.9 & 3.77 & 0.92 \\
\hline PSyz & 150 & 925,611 & 10.8 & 3.27 & 0.86 \\
\hline
\end{tabular}

a Diversity parameters: $S=$ total variants, $N=$ total individuals, $d=$ species richness (Margalef), $H^{\prime \prime}(\operatorname{loge})=$ Shannon, and $1-\lambda=$ Simpson diversity indexes.

b Puccinia psidii populations: Eucalyptus grandis, clone M9 (PEGM9); E. grandis, clone 1600 (PEG1600); E. urophylla (PEU); E. grandis $\times$ brassiana $(\mathrm{PEGB}) ;$ E. grandis $\times$ dunii $(\mathrm{PEGD}) ;$ E. grandis $\times$ urophylla (PEGU); guava (PGuava); jabuticaba (PJab); and syzygium (PSyz). 
samples consisting of $1 \mathrm{bp}(42,43)$. The T-RFLP profiling method was originally developed as a means of genotyping mixed DNA samples (35) and is currently being employed in ecological studies of fungal communities $(12,20,30,32,39,63)$. The profiling of pools of mixed genetic material provides sufficient variability for such DNA mixtures to be characterized and the contributing organisms to be identified (5).

It has been previously suggested that T-RFLP is more sensitive than DGGE for fungal identification $(11,51)$. T-RFLP is significantly less expensive, although clone libraries are most likely the most accurate method for identifying species. It has been suggested that T-RFLP could be used to process large numbers of samples and clone libraries could be used on only selected samples to obtain the identities of key species $(34,57)$. For this reason, we used these three different techniques to access the genetic variability among the sampled $P$. psidii populations.

The molecular analysis of our $P$. psidii populations by PCRDGGE and T-RFLP showed a consistent level of variability among the populations collected from different Eucalyptus spp. and hybrids, as demonstrated by the ANOSIM analysis. The urediniospores were sampled from the same location within hours of each other in an attempt to make the host the principal factor for the selection isolates from each population. Yergeau et al. (59) found a forma specialis due to the presence of intraspecific variation in Fusarium oxysporum and $F$. solani populations or isolates from asparagus using PCR-DGGE. Zhou and Hogetsu (63) used the primers ITS3 and ITS4, which demonstrated intraspecific variation in the T-RFLP profiles for Suillus grevillei, an edible basidiomycete.

Using the similarity data from PCR-DGGE and T-RFLP, we observed a strong clustering between the fungal populations from $E$. grandis PEG1600 and PEGM9, suggesting an important role of the host in pathogen selection within a diverse population. These $E u$ calyptus spp. are the most susceptible to rust infection $(3,18)$. This fact may correlate with the higher level of diversity found in PEG1600, indicating that a variety of fungal genotypes or variants can colonize susceptible plants. The E. urophylla, E. brassiana,
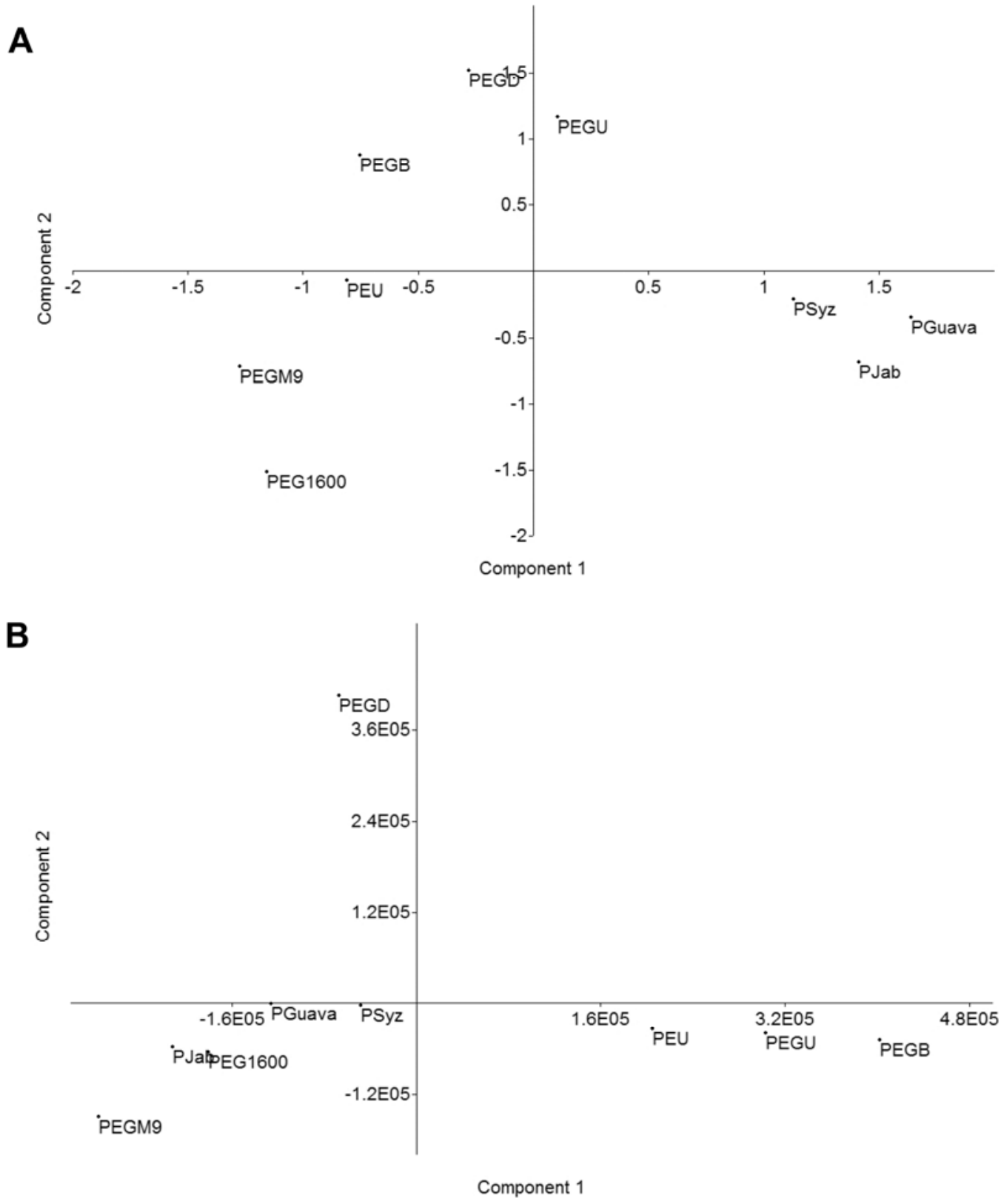

Fig. 4. Principal components analysis based on the band patterns obtained from Puccinia psidii populations using the $\mathbf{A}$, polymerase chain reaction denaturing gradient gel electrophoresis and B, terminal restriction fragment length polymorphism techniques. Values on axes indicate the variance measured for Eucalyptus grandis, clone M9 (PEGM9); E. grandis, clone 1600 (PEG1600); E. urophylla (PEU); E. grandis $\times$ brassiana (PEGB); E. grandis $\times$ dunii $(\mathrm{PEGD}) ;$ E. grandis $\times$ urophylla $(\mathrm{PEGU}) ;$ guava (PGuava); jabuticaba (PJab); and syzygium (PSyz). 
and $E$. dunni clones and their hybrids are considered to possess intermediate resistance against $P$. psidii (60). This may be correlated with the lower diversity indices observed in the PEU, PEB, and PED populations and may indicate a more stringent selection of genotypes or variants capable of colonizing these plants.

Jabuticaba, guava, and syzygium are Myrtaceae spp. that are originally from Brazil (36), South America (38), and Asia (45), respectively. Syzygium was introduced to the Americas before Eucalyptus, according to Morton (40). In 1762, syzygium was brought to Jamaica and, subsequently, to much of the neotropics as a fruit tree. Thus, these species were most likely important sources of inoculum during the adaptation of $P$. psidii to Eucalyptus. This conclusion is suggested by the consistent clustering of the PJab, PGuava, and PSyz populations using both techniques. This is likely a consequence of their high susceptibly, allowing for the maintenance of more diverse populations of $P$. psidii. When the fungus moved to other plant species, such as Eucalyptus spp., a new selection process was introduced due to the new specificities and characteristics of the host.

Initially, we intended to use the rDNA-ITS sequencing to validate the profiles found by PCR-DGGE and T-RFLP as $P$. psidii isolates; however, we quickly observed a large number of SNPs that seemed to be linked to our similarity and diversity analyses. Simon and Weib (50) examined intragenomic polymorphism levels of three nuclear ribosomal loci for Mycosphaerella punctiformis, Davidiella tassiana, Teratosphaeria microspora, and Phoma exigua var. exigua, all important plant-pathogenic fungi, by PCR amplification and cloning. They showed that SNPs are present at an unexpectedly high frequency, similar to our results. Although the possibility of clonal sequence variation due to error introduced during Taq polymerization cannot be excluded, Ganley and Kobayashi (24) suggested that rDNA repeats normally experience "rapid homogenization." This means that mutations are either deleted or preserved during continual unequal recombination, until one variant finally becomes dominant. Consequently, most of the unique polymorphisms identified herein should have arisen after the most recent homogenization event. Wyand and Brown (58) found genetic variability among the forma specialis of Blumeria graminis using this rDNA-ITS region, which was assessed by nucleotide sequencing. These facts highlight the importance of SNPs as a powerful tool for the selection of reliable and convenient markers for differentiation at the subspecies level in Puccinia psidii, which has never been described before.

Due to the small amount of information available about the genetic variability of this pathogen and because, in some cases, the results are contradictory, it is difficult to make correlations between the genetic and physiological variability of $P$. psidii isolates and populations. The physiological variability of $P$. psidii was first described by MacLachlan (37), who characterized different isolates by cross-infection studies and demonstrated that the isolates from Syzygium jambos were able to infect $S$. malaccense but not $\mathrm{Pi}$ menta officinalis and $P$. acris. Aparecido et al. (9) inoculated five different hosts (Corymbia citriodora $=$ E. citriodora, $P$. guajava, $S$. jambos, Eugenia sp., and Eugenia uvalha) with urediniospores from eight different host species. The authors were able to describe four distinct pathogenic groups; however, no molecular studies on the genetic variability of this pathogen were completed.

The study of Puccinia psidii diversity using microsatellites by Zhong et al. (62) found no differences among Hawaiian isolates from different hosts (Metrosideros polymorpha, S. jambos, Melaleuca quinquenervia, Myrtus communis, and others). The authors suggested that this result was a consequence of the recent introduction of the pathogen into the country. Among the pathogens originating in Brazil, the authors were able to identify 11 genotypes; however, no mention was made of a correlation between the genotype and the host species.

Our work with molecular markers is the first to highlight the important role of the host in the selection of specific variants within

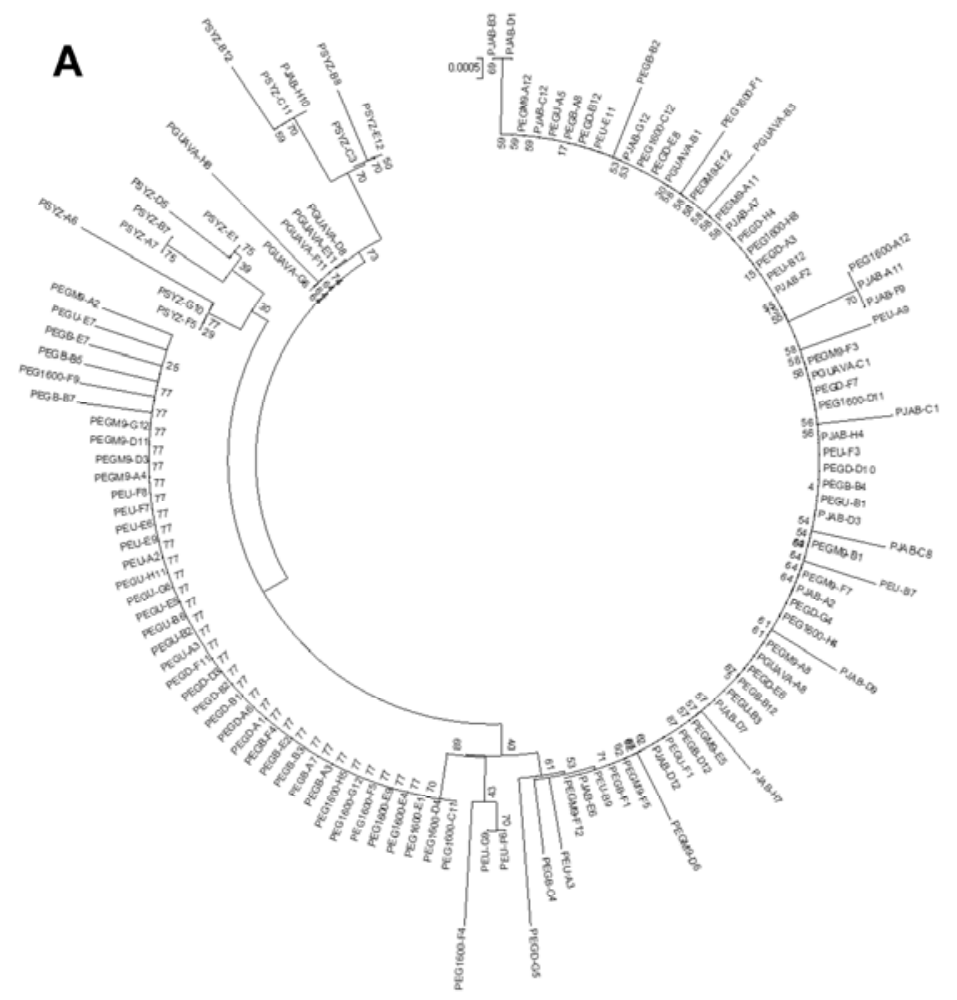

B

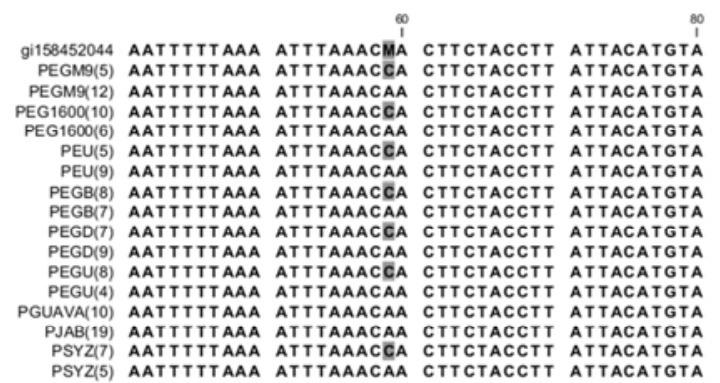

\section{C}

TTTGATGA PEGMY(16) TTGGTATTCC AAAAAGGCA PEG1600(16) TTGGTATTCC AAAAGGCACA CCTGTTTGAG TGTCATGAAA PEU(14) TTGGTATTCC AAAAGGCACA CCTGTTTGAG TGTCATGAAA PEGB(15) TTGGTATTCC AAAAGGCACA CCTGTTTGAG TGTCATGAAA PEGD(15) TTGGTATTCC AAAAGGCACA CCTGTTTGAG TGTCATGAAA PEGU(11) TTGGTATTCC AAAAGGCACA CCTGTTTGAG TGTCATGAAA PGUAVA(9) TTGGTATTCC AAAAGGCACA CCTGTTTGAG TGTCATGAAA PJAB(1) TTGGTATTCC AAAAGGCACA CCTGTTTGAG CGTCATGAAA PJAB(18) TTGGTATTCC AAAAGGCACA CCTGTTTGAG TGTCATGAAA PSYZ(7) TTGGTATTCC AAAAGGCACA CCTGTTTGAG CGTCATGAAA PSYZ(5) TTGGTATTCC AAAAGGCACA CCTGTTTGAG TGTCATGAAA

Fig. 5. Analysis of the ribosomal DNA internal transcribed spacer region (rDNA-ITS) region. A, Neighbor-joining tree of sequences affiliated with Puccinia psidii populations from Eucalyptus grandis, clone M9 (PEGM9); E. grandis, clone 1600 (PEG1600); E. urophylla (PEU); E. grandis $\times$ brassiana (PEGB; E. grandis $\times$ dunii (PEGD); E. grandis $\times$ urophylla (PEGU); guava (PGuava); jabuticaba (PJab); and syzygium (PSyz). Sequences represent distinct clones from each population. The scale bar indicates 0.02 inferred nucleotide substitutions per position. B, Presence of a transversion polymorphism was frequently observed in almost all evaluated populations. C, Transition polymorphism present only in PJab and PSyz. The number of clones with the described polymorphisms from each population is in parentheses. The P. psidii rDNA-ITS region reference exported from GenBank (National Center for Biotechnology Information) correlates with the GenBank accession number EU071048.1. 
the resident pathogen population. This effect can be observed in the $P$. psidii populations characterized from different hosts using culture-independent techniques. These techniques allow for the fast access of genetic variability data from new populations from other sites and the investigation of seasonal variations within and between pathogen populations. The discovery of SNPs among the populations will contribute to a better understanding of pathogen variation. After the confirmation of the stability of these SNPs, their presence may allow for the development of markers or assays to identify races or specific lineages for use in breeding or pathology strategies. In light of this data, the use of single isolates for resistance testing of new clones must be brought into question. Perhaps the use of populations from areas where $P$. psidii is indigenous rather than using isolates that have been continuously generated using the same host will be a better test of natural resistance.

\section{Acknowledgments}

This work was supported by a grant from the Foundation for Research Assistance, São Paulo State, Brazil (grant 2008/50361-1). We thank FAPESP for the fellowship award to M. C. Quecine (Proc. number 10/50445-0), E. Gonzalez (FuturaGene Corporation) for providing the Eucalyptus $P$. psidii populations and other facilities, and R. Mendes at EMBRAPA Environmental for the processing of T-RFLP samples.

\section{Literature Cited}

1. ABRAF. 2011. Brazilian Association of the Producers of Planted Forests ABRAF Statistical Yearbook 2011. http://www.abraflor.org.br/estatisticas/ ABRAF11/ABRAF11-BR.pdf

2. Admassu, B., Friedt, W., and Ordon, F. 2010. Genetic characterization of Puccinia graminis f. sp. tritici populations from Ethiopia by SSRs. J. Phytopathol. 158:806-812.

3. Alfenas, A. C., Zauza, E. A. V., Mafia, R. G., and Assis, T. F. 2004. Doenças causadas por agentes bióticos ou infecciosos. Pages 199-301 in: Clonagem e Doenças do Eucalipto. A. C. Alfenas, E. A. V. Zauza, R. G. Mafia, and T. F. Assis, eds. Editora UFV, Viçosa-MG, Brazil.

4. Ali, S., Gautier, A., Leconte, M., Enjalbert, J., and Vallavieille-Pope, C. 2011. A rapid genotyping method for an obligate fungal pathogen, Puccinia striiformis f. sp. tritici, based on DNA extraction from infected leaf and multiplex PCR genotyping. BMC Res. Notes 4:240.

5. Alvarado, P., and Manjón, J. L. 2009. Selection of enzymes for terminal restriction fragment length polymorphism analysis of fungal internally transcribed spacer sequences. Appl. Environ. Microbiol. 75:4747-4752.

6. Anderson, I. C., Campbell, C. D., and Prosser, J. I. 2003. Diversity of fungi in organic soils under a moorland-Scots pine (Pinus sylvestris L.) gradient. Environ. Microbiol. 5:1121-1132.

7. Andreote, F. D., Azevedo, J. L., and Araújo, W. L. 2009. Assessing the diversity of bacterial communities associated with plants. Braz. J. Microbiol. 40:417-432.

8. Angel, R., Soares, M. I. M., Ungar, E. D., and Gillor, O. 2010. Biogeography of soil archaea and bacteria along a steep precipitation gradient. ISME J. 4:553-563.

9. Aparecido, C. C., Figueiredo, M. B., and Furtado, E. L. 2003. Groups of physiological variability in Puccinia psidii populations. Summa Phytopathol. 29:234-238.

10. Bolton, M. D., Kolmer, J. A., and Garvin, D. F. 2008. Pathogen profile: wheat leaf rust caused by Puccinia triticina. Mol. Plant Pathol. 9:563-575.

11. Brodie, E., Edwards, S., and Clipson, N. 2003. Soil fungal community structure in a temperate upland grassland soil. FEMS Microbiol. Ecol. 45:105-114.

12. Buchan, A., Newell, S. Y., Moreta, J. I. L., and Moran, M. A. 2002. Analysis of internal transcribed spacer (ITS) regions of rRNA genes in fungal communities in a Southeastern U.S. salt marsh. Microbiol. Ecol. 43:329-340.

13. Carson, J. K., Campbell, L., Rooney, D., Clipson, N., and Gleeson, D. B. 2009. Minerals in soil select distinct bacterial communities in their microhabitats. FEMS Microbiol. Ecol. 67:381-388.

14. Clarke, K. R., and Ainsworth, M. 1993. A method of linking multivariate community structure to environmental variables. Mar. Ecol. Prog. Ser. 92:205-219.

15. Clarke, K. R., and Gorley, R. N. 2001. PRIMER v5: User Manual/Tutorial. PRIMER-E Ltd., Plymouth, UK.

16. Coutinho, T. A., Wingfield, M. J., Alfenas, A. C., and Crous, P. W. 1998. Eucalyptus rust: a disease with the potential for serious implications. Plant Dis. 82:819-825.

17. De Carvalho, A. D. O., Alfenas, A. C., Maffia, L. A., and Do Carmo, M. G. F. 1998. Resistance of Eucalyptus species, progenies and provenances to Puccinia psidii Winter. Pesqui. Agropecu. Bras. 33:139-147.

18. Dianese, J. C., Moraes, T. S. A., and Silva, A. R. 1984. Response of Eucalyptus species to field infection by Puccinia psidii. Plant Dis. 68:314-316.

19. Dickie, I. A., and FitzJohn, R. G. 2007. Using terminal restriction fragment length polymorphism (T-RFLP) to identify mycorrhizal fungi: a methods review. Mycorrhiza 17:259-270.

20. Edwards, I. P., Cripliver, J. L., Gillespie, A. R., Johnsen, K. H., Scholler, M., and Turco, R. F. 2004. Nitrogen availability alters macrofungal basidiomycete community structure in optimally fertilized loblolly pine forests. New Phytol. 162:755-770.

21. Feinstein, L. M., Sul, W. J., and Blackwood, C. B. 2009. Assessment of bias associated with incomplete extraction of microbial DNA from soil. Appl. Environ. Microbiol. 75:5428-5433.

22. Ferreira, F. A. 1981. Eucalyptus rust-occurrence, temperature for the germination of urediniospores, the production of teliospores, alternative hosts and resistance. Fitopatol. Bras. 5:603-604.

23. Ferreira, F. A. 1983. Eucalyptus rust. Rev. Árvore 7:91-109.

24. Ganley, A. R. D., and Kobayashi, T. 2007. Highly efficient concerted evolution in the ribosomal DNA repeats: total rDNA repeat variation revealed by whole-genome shotgun sequence data. Genome Res. 17:184-191.

25. Gardes, M., and Bruns, T. D. 1993. ITS primers with enhanced specificity for basidiomycetes - application to the identification of mycorrhizae and rusts. Mol. Ecol. 2:113-118.

26. GIT. 2009. GIT Forestry Consulting, Global Eucalyptus. http://git-forestry.com/

27. Glen, M., Alfenas, A. C., Zauza, E. A. V., Wingfield, M. J., and Mohammed, C. 2007. Puccinia psidii: a threat to the Australian environment and economy-a review. Australas. Plant Pathol. 36:1-16.

28. Hall, T. A. 1999. Bio-Edit: a user-friendly biological sequence alignment editor and analysis program for Windows 95/98/NT. Nucleic Acids Symp. Ser. 41:95-98.

29. Hammer, Ø., Harper, D. A. T., and Ryan, P. D. 2001. PAST: Paleontological Statistics Software Package for Education and Data Analysis. Palaeontologia Electronica. http://palaeo-electronica.org/2001_1/past/issue1_01.htm

30. Jost, L. 2006. Entropy and diversity. Oikos 113:363-375

31. Junghans, D. T. 2000. Quantificação da severidade, herança da resistência e identificação de marcadores RAPD ligados à resistência à ferrugem (Puccinia psidii) em Eucalyptus grandis. Thesis. Universidade Federal de Viçosa, Viçosa, Brazil.

32. Klamer, M., and Hedlund, K. 2004. Fungal diversity in set-aside agricultural soil investigated using terminal-restriction fragment length polymorphism. Soil Biol. Biochem. 36:983-988.

33. Landeweert, R., Leeflang, P., Kuyper, T. W., Hoffland, E., Rosling, A., Wernars, K., and Smit, E. 2003. Molecular identification of ectomycorrhizal mycelium in soil horizons. Appl. Environ. Microbiol. 69:327-333.

34. Lindahl, B. D., Ihrmark, K., Boberg, J., Trumbore, S. E., Högberg, P., Stenlid, J., and Finlay R. D. 2006. Spatial separation of litter decomposition and mycorrhizal nitrogen uptake in a boreal forest. New Phytol. 173:611620.

35. Liu, W., Marsh, T. L., Cheng, H., and Forney, L. J. 1997. Characterization of microbial diversity by determining terminal restriction fragment length polymorphisms of genes encoding 16S rRNA. Appl. Environ. Microbiol. 63:4516-4522.

36. Lorenzi, H. 2002. Árvores brasileiras: manual de identificação e cultivo de plantas arbóreas do Brasil, vol. 1. Instituto Plantarum, Nova Odessa-SP, Brazil.

37. MacLachlan, J. D. 1938. A rust of the pimento tree in Jamaica. Phytopathology 28:157-170.

38. Medina, J. C. 1988. Goiaba. Pages 1-21 in: Cultura. ITAL, Campinas, Brazil.

39. Midgley, D. J., Saleeba, J. A., Stewart, M. I., Simpson, A. E., and McGee, P. A. 2007. Molecular diversity of soil basidiomycete communities in northern central New South Wales, Australia. Mycol. Res. 111:370-378.

40. Morton, J. F. 1987. Fruits of Warm Climate. Miami, FL.

41. Muyzer, G., De Waal, E. C., and Uitterlinden, A. G. 1993. Profiling of complex microbial populations by denaturing gradient gel electrophoresis analysis of polymerase chain reaction-amplified genes coding for $16 \mathrm{~S}$ rRNA. Appl. Environ. Microbiol. 59:695-700.

42. Myers, R. M., Fischer, S. G., Lerman, L. S., and Maniatis, T. 1985. Nearly all single base substitutions in DNA fragments joined to a GC-clamp can be detected by denaturing gradient gelelectrophoresis. Nucleic Acids Res. 13:3131-3145.

43. Myers, R. M., Maniatis, T., and Lerman, L. S. 1987. Detection andlocalization of a single base changes by denaturing gradient gelelectrophoresis. Pages 501-527 in: Recombinant DNA, part F. R. Wu, ed. Academic Press, San Diego, CA.

44. Ordoñez, M. E., Germán, S. E., and Kolmer, J. A. 2010. Genetic differentiation within the Puccinia triticina population in South America and comparison with the North American population suggests common ancestry and intercontinental migration. Phytopathology 100:376-383.

45. Pio-Correa, M. 1969. Dicionário das plantas úteis do Brasil e das exóticas cultivadas. Instituto Brasileiro de Desenvolvimento Florestal, Rio de Janeiro, Brazil

46. Ramette, A. 2007. Multivariate analyses in microbial ecology. FEMS Microbiol. Ecol. 62:142-160.

47. Ranjard, L., Poly, F., and Nazaret, S. 2000. Monitoring complex bacterial communities using culture-independent molecular techniques: application to soil environment. Res. Microbiol. 151:167-177. 
48. Sambrook, J., and Russel, D. W. 2001. Molecular Cloning: A Laboratory Manual. Cold Spring Harbor Laboratory Press, Cold Spring Harbor, NY.

49. Shan, W. X., Chen, S., Kang, Z. S., Wu, L., and Li, Z. 1998. Genetic diversity in Puccinia striiformis Westend. f. sp. tritici revealed by pathogen genome-specific repetitive sequence Can. J. Bot. 76:587.595.

50. Simon, U. K., and Weiß, M. 2008. Intragenomic Variation of fungal ribosomal Genes is higher than previously thought. Mol. Biol. Evol. 25:22512254.

51. Singh, B. K., Munro, S., Reid, E., Ord, B., Potts, J. M., Paterson, E., and Millard, P. 2006. Investigating microbial community structure in soils by physiological, biochemical and molecular fingerprinting methods. Eur. J. Soil Sci. 57:72-82.

52. Tamura, K., Peterson, D., Peterson, N., Stecher, G., Nei, M., and Kumar, S. 2011. MEGA5: molecular evolutionary genetics analysis using maximum likelihood, evolutionary distance, and maximum parsimony methods. Mol. Biol. Evol. 28:2731-2739.

53. Ter Braak, C. J. F., and Smilauer, P. 2002. CANOCO Reference Manual and CanoDraw for Windows User's Guide: Software for Canonical Community Ordination (version 4.5). Microcomputer Power, Ithaca, NY.

54. Thompson, J. D., Higgins, D. G., and Gibson, T. J. 1994. CLUSTAL W: improving the sensitivity of progressive multiple sequence alignment through sequence weighting, position-specific gap penalties and weight matrix choice. Nucleic Acids Res. 22:4673-4680.

55. Van Elsas, J. D., Duarte, G. F., Keijzer-Woltersa, A., and Smit, E. 2000. Analysis of the dynamics of fungal communities in soil via fungal-specific PCR of soil DNA followed by denaturing gradient gel electrophoresis. J.
Microbiol. Methods 43:133-151.

56. Villaréal, L. M. M. A., Lannou, C., de Vallavieille-Pope, C., and Neema, C. 2002. Genetic variability in Puccinia striiformis f. sp. tritici populations sampled on a local scale during natural epidemics. Appl. Environ. Microbiol. 68:6138-6145.

57. Widmer, F., Hartmann, M., Frey, B., and Kölliker, R. 2006. A novel strategy to extract specific phylogenetic sequence information from community TRFLP. J. Microbiol. Methods 66:512-529.

58. Wyand, R. A., and Brown, J. K. M. 2003. Genetic and forma specialis diversity in Blumeria graminis of cereals and its implications for host-pathogen co-evolution. Mol. Plant Pathol. 4:187-198.

59. Yergeau, E., Filion, M., Vujanovic, V., and St-Arnaud, M. 2005. A PCR denaturing gradient gel electrophoresis approach to assess Fusarium diversity in asparagus. J. Microbiol. Methods 60:143-154.

60. Zauza, E., Alfenas, A. C., Old, K, Couto, M. M. F., Graça, R. N., and Maffia, L. A.. 2010. Myrtaceae species resistance to rust caused by Puccinia psidii. Autralas. Plant Pathol. 39:406-411.

61. Zhong, S., Yang, B., and Alfenas, A. C. 2008. Development of microsatellite markers for the guava rust fungus, Puccinia psidii. Mol. Ecol. Resour. 8:348-350.

62. Zhong, S., Yang, B., and Puri, K. D. 2011. Characterization of Puccinia psidii isolates in Hawaii using microsatellite DNA markers. J. Gen. Plan Pathol. 77:178-181.

63. Zhou, Z. H., and Hogetsu, T. 2002. Subterranean community structure of ectomycorrhizal fungi under Suillus grevillei sporocarps in a Larix kaempferi forest. New Phytol. 154:529-539. 